\title{
Life in a monastic lab
}

\section{A vocational career.}

\section{Joost Uitdehaag}

The bell rang for evensong as Jorge attached the power-pack and started his gel. He smiled. He liked it when everything was exactly in time. He left the lab and walked towards the chapel. On the way he met his older friend, Anselm, who hurried along as usual.

"Slow down," Jorge whispered. "What's the use?"

"What's the use of being slow?"

"Slow is about taking aim."

"Where did you get that from?"

"A penitence session."

"Don't mention those."

"You mean they are counterintuitive to a fearful old individualist. Really, you should join. Maybe even tonight?"

Anselm just smiled. They stopped talking as they entered the chapel. It had a pleasing retro ambience - its design influenced by Le Corbusier's famous Chapel of Notre Dame - amid the lab complex of the Benedictine Order for Oncology, set in a remote valley in the Ardennes.

For Jorge, his lab was one of the good things the great crisis had brought: a total reshuffling of drug research, an injection of idealism in a world of self-interest. That the injection had come from religion was no surprise for Jorge. Management gurus had been courting religious rules long before the crisis. Live for yourself or for your community, that was the post-crisis choice, and science and religion were both community efforts. Scientific monasticism was a new synthesis, the ultimate way of serving society.

All the scientists had gathered in the chapel, and they started a medieval hymn. Singing together was supposed to stimulate collaboration and equality, but Jorge was still bad at it. During the hymn he worried about Anselm. His friend had started to complain again about giving up the 'self' side of science. He was a former academic and had this all-pervading desire to compete and establish his name, but within the Order that would get him into trouble. They gave you a permanent contract and a budget so there was no need to worry about grants or tenure, but in return the Order demanded no double work, no egos and no secrecy.

If only Anselm had been a pharma man. Novices from industry generally had less trouble giving up the self-side. But then again, those who had worked through the Barren Years had generally less passion for their jobs than a zebrafish for a barcode.
Jorge wondered why people could not simply decide if they really wanted to live their undergraduate dreams and work on curing disease, or if they wanted something else. Anselm always said he was naive.

"Idealists have a history of getting hurt," he would say.

"Isn't that the whole point," Jorge would reply, "that contributing costs you?"

"You just haven't suffered yet."

Anselm had been damaged by his time in academia; that much Jorge knew. That's why doing penitence tonight would be good for him. It would give him that perfect feeling that all was well and that he

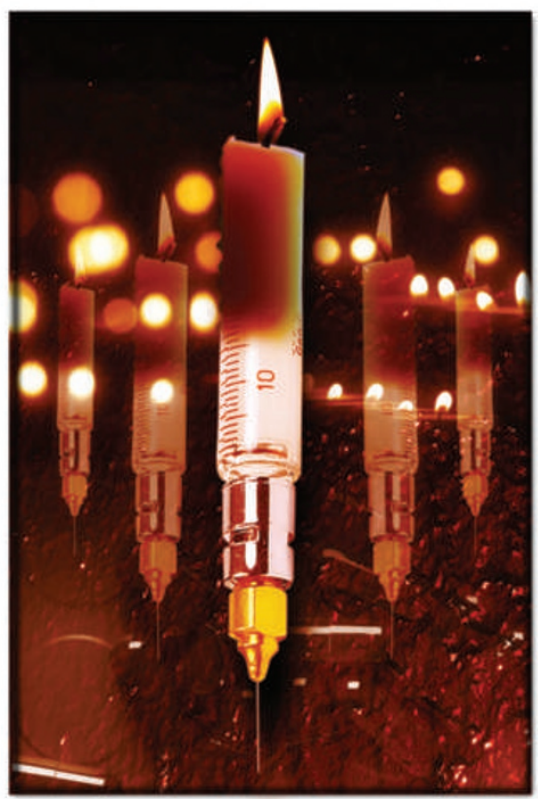

was living a good life. If only Jorge could convince him.

The singing finished and Abbott Fra Paolini spoke about the Barren Years. That was the time when ever larger pharma companies and a society ever more hostile to them together had driven the cost of developing a drug to $\$ 2$ billion. And what was considered worse: to the cost of a thousand scientific careers. It had been the scientific equivalent of the Somme offensive.

With a wide movement of his hands, Fra Paolini spoke of the day when seven expharma scientists had taken up vows in a monastery to continue a 'killed' project. It was a golden move. Their vows of poverty (no patenting, no bonuses), chastity (do nothing that satisfies only yourself) and obedience (listen to what patients want) were the right guarantees for patient organizations and health insurers to pour money into monastic research labs. In the past year, these labs had developed and published the majority of new therapies (generics companies usually took up marketing them).

After the ceremony, Jorge waited for Anselm.

"Why do you fear a penitence session? You know they did this all the time in the old days: remember Borel and cyclosporine? It's part of our tradition. It is why the public likes us."

"I don't fear it. I just don't think it's rational. It's hysterics."

"I'm not hysterical."

"But you're not joining tonight are you?"

Jorge did not answer. Anselm stopped walking and gave him an angry look.

"You are! That would be what, the second time in a month? You're wasting yourself."

"The supervisory committee allowed me."

"Sure they do. Bunch of vampires, they are."

"It has nothing to do with them and all with me," Jorge hated being berated.

"I won't allow you," Anselm said.

"What do you want to do? Swap places?"

"If that's what it takes."

Jorge was amazed. Was getting Anselm to do penitence really this simple? Was he really going to give up his principle for a worry about a friend? Anselm never ceased to surprise him.

"All right," he said.

In the monastery, most clinical trials were carried out in the infirmatorium, on a veranda filled with the evening's sunlight. Jorge was sitting at Anselm's bed.

"You are getting chimidinib," Jorge said, "the first inhibitor of the Chung-Mi variant isomerase. Have you seen the preclinical data?"

"Yes. They're ok."

Jorge rolled up Anselm's sleeve as a nurse prepared the drip.

"You want some blood for western blotting tomorrow?"

Anselm nodded. "Don't worry," he said as the compound started to enter his body.

But Jorge felt guilty. That night he did the only sensible thing: he lit a candle for his friend.

Joost Uitdehaag lives in the Netherlands and works for a drug-discovery company. His writing includes literature on drug discovery and fantasy stories for Dutch magazines.

Join the discussion of Futures in Nature at http://tinyurl.com/kkh3kt 